\title{
Cancellation of Surgeries by the Patient, Doctor or Institution: An Approach to Legal Ethical Aspects
}

\author{
Diaz-Perez Anderson ${ }^{1,2}$, Andrea Candelario Vargas ${ }^{1}$, Katherine Urbina Fuentes ${ }^{1}$, Arley Denisse Vega Ochoa ${ }^{1}$, \\ Lina Patricia Camacho Nuñez ${ }^{1}$, Maria Isabel Gina Cuello Orozco ${ }^{1} \&$ Zoraima Romero Oñate $^{1}$ \\ ${ }^{1}$ Universidad Popular del Cesar, Facultad de Ciencias de la Salud, Programa de Instrumentacion Quirurgica, \\ Valledupar, Colombia \\ ${ }^{2}$ Universidad Simón Bolívar, Facultad de Ciencias Sociales y Humanas, Barranquilla, Colombia \\ Correspondence: Diaz-Perez Anderson, Universidad Popular del Cesar, Facultad de Ciencias de la Salud, \\ Programa de Instrumentacion Quirurgica, Valledupar, Colombia. Orcid: 0000-0003-2448-0953. E-mail: \\ ander2711@gmail.com
}

Received: May 24, 2019 Accepted: June 21, 2019 Online Published: July 1, 2019

doi:10.5539/gjhs.v11n9p34

URL: https://doi.org/10.5539/gjhs.v11n9p34

\begin{abstract}
Introduction: The cancellation of surgery represents a dilemma in establishing relatively adequate cancellation rates according to the factor, because each institution and surgical specialty have different dynamics. Objective: Describe the types of factors present for the cancellation of surgeries in a health institution. Colombia (2017-2018).

Methodology: Descriptive, retrospective, cross-sectional study. We reviewed (3339) records of scheduled surgeries from January to December 2017. In 2018 they were reviewed (1733) between January and June. A total of (5072) records of a Third Level Health Institution of the Department of Cesar/Colombia were reviewed. The Neuronal Multilayer Perceptron Network model and the Gini coefficient were applied to determine the most important factor and therefore the inequality between them.

Results: In 2017, there was a surgical cancellation rate of $4 \%$ of the total number of scheduled surgeries (3339). For the year 2018, the rate was 3\% of the total of scheduled surgeries (1733). The most important factor was due to the patient's adverse conditions. The surgical specialties that had the highest number of cancellations were general surgery followed by orthopedics.

Conclusion: An evaluation of the factors for the cancellation of programmed surgeries with a high coefficient of inequality is described. In addition, the most important factor was related to the patient. Prospective studies by specialty are proposed for the design of solution and monitoring strategies to avoid surgical cancellations.
\end{abstract}

Keywords: Cancellation, adverse event, factors, surgery, medical errors, Gini coefficient, Neural Multilayer Network (NMN), World Health Organization (WHO)

\section{Introduction}

According to the World Health Organization, public health problems have changed significantly, which has influenced the increase in surgical interventions. In the world, approximately 230 million major surgical procedures are performed per year according to (Gaviria-García, Lastre-Amell, \& Suárez-Villa, 2014; Quesquén \& Alfredo, 2018), which requires a significant investment in technology and training of human resources. Studies such as the one proposed by (Eugenio Ortiz \& Alvarado Rodriguez, 2014), describe that this investment should be around $30.1 \%$ of the hospital total budget, since the suspension of a scheduled surgery affects the institution much more financially, without mentioning lawsuits presented by patients and their families due to the negative perception they have from the institution (Barbenza, 2018; Trouiller, Lopard, Mantz, \& Farman, 2012; Vayre \& Vannineuse, 2003). Therefore, surgery scheduling has an important purpose in the management plan of the patient, since a failure in the attention could cause negative circumstances which might be preventable when a cause-effect association it is established, leading to legal and ethical processes (Antaurco \& Méndez, 2018).

The factors for surgery cancellation are related to resources mismanaging, such as: insufficient surgery utensils or equipment, lack of sterile clothing, lack of personnel that work in the surgery room, among other causes such as: rescheduling of a programmed procedure for an emergency procedure, greatly affecting the quality of care and well-being of users, increasing costs and the hospitalization time, causing anguish to patients and their caregivers 
(Gaviria-García et al., 2014).

The attributable factors for a surgery to be cancelled are divided into three: those related to the institution, the doctor or health personnel and the patient (Table 1).

Table 1. Causes related to surgeries cancellation

Causes for surgery
cancellation

\begin{tabular}{ll}
\hline \multirow{2}{*}{ Lack of surgical material } & $\begin{array}{l}\text { It is a purely institutional problem, lack of clothing, lack of prosthetic material, among } \\
\text { others.(De la Cruz Injante, Zapatero Choy, \& Medina Gaspar, 2018; Gamboa Niño \& } \\
\text { Rodríguez Montaño, 2017; García Cordova, 2019; Gaviria-García et al., 2014; Guillén et } \\
\text { al., 2012). }\end{array}$ \\
\hline \multirow{3}{*}{ Tontaminated operating rooms } & $\begin{array}{l}\text { The fact that different surgical specialties use the same operating rooms raises the risk of } \\
\text { infection to patients (De la Cruz Injante et al., 2018; Gamboa Niño \& Rodríguez Montaño, } \\
\text { 2017; García Cordova, 2019; Gaviria-García et al., 2014; Guillén et al., 2012). }\end{array}$ \\
\hline Lack of blood & $\begin{array}{l}\text { The absence of a blood bank, not having the adequate amount or type of blood (De la Cruz } \\
\text { Injante et al., 2018; Gamboa Niño \& Rodríguez Montaño, 2017; García Cordova, 2019; } \\
\text { Gaviria-García et al., 2014; Guillén et al., 2012). }\end{array}$ \\
\hline
\end{tabular}
The large number of patients and the shortage of personnel influence that the clinical

Lack of patient's medical record records are not in the operating room on the day of surgery (De la Cruz Injante et al., 2018; Gamboa Niño \& Rodríguez Montaño, 2017; García Cordova, 2019; Gaviria-García et al., 2014; Guillén et al., 2012).

Patient income increases the waiting time for the scheduling of a surgery and makes the

Bad scheduling surgery shifts insufficient, causing an excessive number of surgical procedures to be programmed. (De la Cruz Injante et al., 2018; Gamboa Niño \& Rodríguez Montaño, 2017; García Cordova, 2019; Gaviria-García et al., 2014; Guillén et al., 2012).

\begin{tabular}{|c|c|}
\hline Outdated auxiliary exams & $\begin{array}{l}\text { Auxiliary exams as well as interconsultations are valid for } 6 \text { months, it is not uncommon to } \\
\text { find patients with outdated exams (De la Cruz Injante et al., 2018; Gamboa Niño \& } \\
\text { Rodríguez Montaño, 2017; García Cordova, 2019; Gaviria-García et al., 2014; Guillén et } \\
\text { al., 2012). }\end{array}$ \\
\hline Incomplete study & $\begin{array}{l}\text { When is needed more than one pre-surgery study or lack of pre-surgery assessment (De la } \\
\text { Cruz Injante et al., 2018; Gamboa Niño \& Rodríguez Montaño, 2017; García Cordova, } \\
\text { 2019; Gaviria-García et al., 2014; Guillén et al., 2012). }\end{array}$ \\
\hline Surgical time exceeded & $\begin{array}{l}\text { The use of surgery room in the previous procedure due to its complexity or its late start (De } \\
\text { la Cruz Injante et al., 2018; Gamboa Niño \& Rodríguez Montaño, 2017; García Cordova, } \\
\text { 2019; Gaviria-García et al., 2014; Guillén et al., 2012). }\end{array}$ \\
\hline $\begin{array}{l}\text { Therapeutic-diagnostic } \\
\text { inconsistency }\end{array}$ & $\begin{array}{l}\text { Due to a diagnostic error or an error during the treatment, causes the scheduling for } \\
\text { insufficient or unnecessary surgeries (De la Cruz Injante et al., 2018; Gamboa Niño \& } \\
\text { Rodríguez Montaño, 2017; García Cordova, 2019; Gaviria-García et al., 2014; Guillén et } \\
\text { al., 2012). }\end{array}$ \\
\hline Absence of a surgeon & $\begin{array}{l}\text { This cause is placed in the group of causes related to the planning and scheduling of human } \\
\text { resources (surgical team) (De la Cruz Injante et al., 2018; Gamboa Niño \& Rodríguez } \\
\text { Montaño, 2017; García Cordova, 2019; Gaviria-García et al., 2014; Guillén et al., 2012).. }\end{array}$ \\
\hline The patient did not show up & $\begin{array}{l}\text { Corresponds to personal situations of the patient, of which no record is made of the exact } \\
\text { reason (Guillén et al., 2012; Gaviria-García et al., 2014; Gamboa Niño \& Rodríguez } \\
\text { Montaño, 2017; De la Cruz Injante et al., 2018; García Cordova, 2019). }\end{array}$ \\
\hline Improvement of the patient & $\begin{array}{l}\text { There are situations in clinical practice in which a certain patient is scheduled for the } \\
\text { removal of a tumor, which disappears at the time of surgery (De la Cruz Injante et al., 2018; } \\
\text { Gamboa Niño \& Rodríguez Montaño, 2017; García Cordova, 2019; Gaviria-García et al., } \\
\text { 2014; Guillén et al., 2012). }\end{array}$ \\
\hline
\end{tabular}


Incorrect preparation for not Patient and family members should be given instructions on fasting time, and insist on following up correctly the compliance (De la Cruz Injante et al., 2018; Gamboa Niño \& Rodríguez Montaño, 2017; medical instructions García Cordova, 2019; Gaviria-García et al., 2014; Guillén et al., 2012)..

Since it has not been explained to the patient on what consist the surgery, even though

Patient does not accept surgical procedure she/he has signed an informed consent. This cause might be related to the patient (fear, anxiety, etc.) and also to the hospital staff (missing of proper process of taking informed consent) (De la Cruz Injante et al., 2018; Gamboa Niño \& Rodríguez Montaño, 2017; García Cordova, 2019; Gaviria-García et al., 2014; Guillén et al., 2012)..

The common disease is an unpredictable cause of surgical suspension. Recent studies indicate that the anesthesiologist suspends elective surgery more because the fear of legal Unfavorable clinical condition (severe illness) medical problems than medical complications (De la Cruz Injante et al., 2018; Gamboa Niño \& Rodríguez Montaño, 2017; García Cordova, 2019; Gaviria-García et al., 2014; Guillén et al., 2012).

Decompensation of chronic
disease

Tension due to the proximity of surgery usually exacerbates hypertension, which causes the need to increase antihypertensive treatment or improve white coat hypertension (Guillén et al., 2012)..

Pregnancy

Reproductive age could reschedule surgical treatment (De la Cruz Injante et al., 2018; Gamboa Niño \& Rodríguez Montaño, 2017; García Cordova, 2019; Gaviria-García et al., 2014; Guillén et al., 2012)..

The cancellation of surgeries has been studied exhaustively using a large number of methodologies, but the vast majority are retrospective, using statistical calculations that range from simple ones as reporting the rates of cancellation to most advanced approaches, as the one intended in the present investigation. The studies seek to contribute with a greater understanding of what are the reasons for the cancellation of surgery, understanding that some are avoidable and others not so much as it is exposed by (Fayed, Elkouny, Zoughaibi, \& Wahabi, 2016)

Avoid the cancellation of surgeries should be a commitment that is reflected in an institutional policy that seeks to reduce the factors associated with it. For this, it is recommended that health professionals redesign techniques related to surgery scheduling, training of human resources, excellence in the management of materials and supplies, among others, additionally, to apply control methods to correct and learn from the problems (Nepote, Monteiro, \& Hardy, 2009).

Ethical behavior has always been deeply rooted in the surgical culture. However, each time there are more cases of claims filed by patients for the cancellation of surgeries when it does not depend on them. In the present investigation the most frequent failures that lead to the cancellation of surgeries are described which can be typified as errors that can be determined as nexus that even lead to complications that can be associated with medical negligence. The Sentence 17.918 of the Council of State Medical Responsibility describes that each case that contributes to the cancellation of surgeries as a criterion of the a quo must be analyzed in a particular and concrete way, in the sub examine case, it must be demonstrated a clear failure of the hospital medical service, in the case of the body of evidence, it is specifically demonstrated that the damage suffered by the victim is not caused by force majeure or is attributable to the negligent conduct of health personnel or the institution (Gaviria Gomez, 2015; Díaz-Pérez, 2019).

The constant error of surgeries cancellation could be seen as a routine of the processes (routine error) (Aguirre-Gas \& Vázquez-Estupiñán, 2006; Vargas Villanueva, 2018). However, these institutions should be focused on the consequences that might affect the patient and the family. There are many studies on surgeries cancellation that mention the infection risks to which the patient is exposed due to the increase in hospital stance when she/he was previously hospitalized (Díaz Koo, 2019; Dobarro et al., 2019; Guillén et al., 2012), therefore it can be understood as unsafe care and therefore subject to lawsuit (Vargas Villanueva, 2018; Vayre \& Vannineuse, 2003). To sum up, good medical practice in terms of application and knowledge should provide alternative solutions to avoid the cancellation of the surgical process as much as possible (Antaurco \& Méndez, 2018; Corona Martínez \& Fonseca Hernández, 2010). The cancellation of scheduled surgeries is a negative indicator of the care quality service that affects not only the patient but also his family (Cho, Lee, Lee, Kim, \& Kim, 2019; Perroca, Jericó, \& Facundin, 2007).

The initiative from the institutional point of view must be to establish a commitment culture from the health care personnel, on which the patient safety depends not only on the care area, but also on all the dependencies directly or indirectly involved with the patient attention (Trincado Agudo \& Fernández Caballero, 1995). As a strategy, a 
follow-up system for patients scheduled for surgery before their transfer to the operating room, in order to verify their well-being, safety and physical conditions as proposed by (Antaurco \& Méndez, 2018).

Numerous studies have shown that the failures associated with surgeries cancellation are mainly due to the lack of knowledge of the patient's clinical conditions, which are caused by an insufficient preoperative evaluation, that is to say, preventable (Cho et al., 2019; Dobarro et al., 2019; Muñoz et al., 2018).

It is estimated that the cancellation of an optional surgery has a cost on average of 198,000 USD per patient (Macarthur, Macarthur, \& Bevan, 1995; Perroca et al., 2007; Olguín-Juárez, 2018). In 1996, the cost per minute of surgical time calculated was 8.13 USD. In 1999 it was calculated in 13.53 USD per minute ("Applications of Information Systems to Operating Room Scheduling | Anesthesiology | ASA Publications», s. f.; Olguín-Juárez, 2018), taking into account that these costs change as the volume of surgeries increases as described by (Canales, Macario, \& Krummel, 2001). It is clear that the cancellation of surgery brings complaints and lawsuits (Tait, Voepel-Lewis, Munro, Gutstein, \& Reynolds, 1997) in addition, the increase in hospital costs due to the patient permanence in its facilities (Tait et al., 1997; Beijnen et al., 2018).

\subsection{Objective}

Describe the types of factors present for the cancellation of surgeries in a health institution. Colombia, 2017-2018.

\section{Method}

A descriptive, retrospective cross-sectional study was proposed. There were reviewed (3339) scheduled surgeries records from January to December 2017 and (1733) from January to June 2018 for a total of (5072) records of a Third Level Institution from the Department of Cesar/Colombia. It was used as information collection instrument a format sheet, which includes the factors attributable to surgeries cancellation. The information was analyzed utilizing descriptive statistics parameters of type percentages (\%) and frequencies (n) and the Neuronal Multilayer Perceptron Network model through the software SPSS $21 \circledR$. In addition, the Gini coefficient was calculated for measuring the degree of inequality or proportion of surgeries canceled taking into account the attributable factors as Patient, Physician and Hospital.

Ethical component. The study conforms to the principles of the Declaration of Helsinki, safeguarding principles such as privacy and confidentiality, safeguarding the identity of both patients and health professionals, for which it was approved by the research committee of the program of Surgical Instrumentation of the Popular University of Cesar.

\section{Results}

Table 2 shows that between the first semester of 2017 and 2018 cancelled surgeries decreased on a percentage difference of $(17.3 \%-7.2 \%=10.1 \%)$. Furthermore, Table 2 shows that the procedures in which most of the surgeries programmed were: General Surgery, Orthopedy, Gynecology and Otorhinolaryngology. However, among all the specialties mentioned there is a non-significant comparative proportion between surgeries canceled both in the year and in surgical specialty. (Table 2)

Table 3 shows that in 2017 of the (32) surgeries that were cancelled in Orthopedy specialty, $41 \%$ were due to adverse conditions related to the patient. During the year 2018 24\% of surgeries canceled had as main cause the lack of equipment and instrumentation (See Table 3). The major cause of cancellation in Gynecology specialty during 2017 was related to adverse conditions present by the patient on $70.3 \%$ of cases. Similarly, throughout 2018 patient's adverse conditions with $62.5 \%$, was the first cause of surgery cancellation. (Table 3 )

In the specialty of General Surgery in 2017, (47) surgeries were cancelled and $34 \%$ of these cancellations were due to adverse conditions presented by the patient. In 2018, the most prevalent cause for surgery cancellation was as the previous year because adverse patient conditions with $50 \%$ from the overall number of cancellations. (Table 3)

In Otolaryngology during 2017, 50\% of surgeries cancelled were due to the anesthesiologist. All through 2018 the only cause for surgery cancellation was also due anesthesia. (Table 3)

In 2017 , on what concerns to Neurosurgery specialty, $66.7 \%$ of surgical procedures were cancelled due to adverse conditions related to the patient, followed by inconsistencies in the laboratory results with $33.3 \%$ of the total cancellations. During 2018 the only cause of cancellation were the lack of beds, errors in admission, repeated scheduling, and lack of personnel, among others. (Table 3)

In what concerns to the Urology specialty according to the analyzed records, in 2017 were cancelled due patient's adverse conditions on the $50 \%$ and by considerations of the anesthesiologist the other $50 \%$. During 2018 the only cause of cancellation of the surgery was due to the patient's adverse conditions with $100 \%$. (Table 3) 
Table 2. Scheduled Surgery versus Cancelled Surgery

\begin{tabular}{|c|c|c|c|c|c|c|c|c|c|c|c|c|}
\hline \multicolumn{4}{|c|}{ Orthopedy (2017) } & \multicolumn{3}{|c|}{ Orthopedy (2018) } & \multicolumn{3}{|c|}{ Otolaryngology (2017) } & \multicolumn{3}{|c|}{ Otolaryngology (2018) } \\
\hline Month & $\begin{array}{l}\text { Scheduled } \\
\mathrm{n}(\%)\end{array}$ & $\begin{array}{l}\text { Cancelled. } \\
\mathrm{n}(\%)\end{array}$ & $\begin{array}{l}\text { Total } \\
\text { performed } \\
\mathrm{n}(\%)\end{array}$ & $\begin{array}{l}\text { Scheduled } \\
\mathrm{n}(\%)\end{array}$ & $\begin{array}{l}\text { Cancelled. } \\
\mathrm{n}(\%)\end{array}$ & $\begin{array}{l}\text { Total } \\
\text { performed } \\
\mathrm{n}(\%)\end{array}$ & $\begin{array}{l}\text { Scheduled } \\
\mathrm{n}(\%)\end{array}$ & $\begin{array}{l}\text { Cancelled. } \\
\mathrm{n}(\%)\end{array}$ & $\begin{array}{l}\text { Total } \\
\text { performed } \\
\mathrm{n}(\%)\end{array}$ & $\begin{array}{l}\text { Scheduled } \\
\mathrm{n}(\%)\end{array}$ & $\begin{array}{l}\text { Cancelled. } \\
\mathrm{n}(\%)\end{array}$ & $\begin{array}{l}\text { Total } \\
\text { performed } \\
\text { n (\%) }\end{array}$ \\
\hline January & $51(7.8)$ & $2(0.3)$ & $49(7.5)$ & $57(17.7)$ & $4(1.2)$ & $53(16.5)$ & $67(8.6)$ & $0(0.0)$ & $67(8.6)$ & $94(19.9)$ & $0(0.0)$ & $94(19.9)$ \\
\hline February & $53(8.1)$ & $2(0.3)$ & $51(7.8)$ & $38(11.8)$ & $2(0.6)$ & $36(11.2)$ & $72(9.3)$ & $1(0.1)$ & $71(9.2)$ & $87(18.4)$ & $0(0.0)$ & $87(18.4)$ \\
\hline March & $64(9.8)$ & $4(0.6)$ & $60(9.2)$ & $59(18.3)$ & $2(0.6)$ & $57(17.7)$ & $57(7.4)$ & $1(0.1)$ & $56(7.3)$ & $75(15.9)$ & $0(0.0)$ & $75(15.9)$ \\
\hline April & $45(6.9)$ & $1(0.2)$ & $44(6.7)$ & $57(17.7)$ & $2(0.6)$ & $55(17.1)$ & $80(10.3)$ & $0(0.0)$ & $80(10.3)$ & $58(12.3)$ & $0(0.0)$ & $58(12.3)$ \\
\hline May & $76(11.6)$ & $3(0.5)$ & $73(11.2)$ & $66(20.5)$ & $3(0.9)$ & $63(19.6)$ & $69(8.9)$ & $2(0.3)$ & $67(8.6)$ & $91(19.2)$ & $1(0.2)$ & $90(19)$ \\
\hline June & $55(8.4)$ & $3(0.5)$ & $52(8.0)$ & $45(14)$ & $4(1.2)$ & $41(12.7)$ & $46(5.9)$ & $0(0.0)$ & $46(5.9)$ & $68(14.4)$ & $0(0.0)$ & $68(14.4)$ \\
\hline July & $49(7.5)$ & $3(0.5)$ & $46(7)$ & $0(0.0)$ & $0(0.0)$ & $0(0.0)$ & $93(12)$ & $0(0.0)$ & $93(12)$ & $0(0.0)$ & $0(0.0)$ & $0(0.0)$ \\
\hline August & $60(9.2)$ & $4(0.6)$ & $56(8.6)$ & $0(0.0)$ & $0(0.0)$ & $0(0.0)$ & $45(5.8)$ & $1(0.1)$ & $44(5.7)$ & $0(0.0)$ & $0(0.0)$ & $0(0.0)$ \\
\hline September & $46(7)$ & $2(0.3)$ & $44(6.7)$ & $0(0.0)$ & $0(0.0)$ & $0(0.0)$ & $47(6.1)$ & $2(0.3)$ & $45(5.8)$ & $0(0.0)$ & $0(0.0)$ & $0(0.0)$ \\
\hline October & $55(8.4)$ & $5(0.8)$ & $50(7.6)$ & $0(0.0)$ & $0(0.0)$ & $0(0.0)$ & $92(11.9)$ & $0(0.0)$ & $92(11.9)$ & $0(0.0)$ & $0(0.0)$ & $0(0.0)$ \\
\hline November & $59(9)$ & $0(0.0)$ & $59(9)$ & $0(0.0)$ & $0(0.0)$ & $0(0.0)$ & $46(5.9)$ & $0(0.0)$ & $46(5.9)$ & $0(0.0)$ & $0(0.0)$ & $0(0.0)$ \\
\hline December & $41(6.3)$ & $3(0.5)$ & $38(5.8)$ & $0(0.0)$ & $0(0.0)$ & $0(0.0)$ & $61(7.8)$ & $1(0.1)$ & $60(7.7)$ & $0(0.0)$ & $0(0.0)$ & $0(0.0)$ \\
\hline \multirow[t]{2}{*}{ Total } & $654(100)$ & $32(4.9)$ & $622(95.1)$ & $322(100)$ & $17(5.3)$ & $305(94.7)$ & $775(100)$ & $8(1.0)$ & $768(99.1)$ & $473(100)$ & $1(0.2)$ & $472(99.8)$ \\
\hline & \multicolumn{3}{|c|}{ Gynecology (2017) } & \multicolumn{3}{|c|}{ Gynecology (2018) } & \multicolumn{3}{|c|}{ Neurosurgery (2017) } & \multicolumn{3}{|c|}{ Neurosurgery (2018) } \\
\hline January & $16(7.5)$ & $6(2.8)$ & $10(4.7)$ & $10(9.0)$ & $0(0.0)$ & $10(9.0)$ & $3(7)$ & $0(0.0)$ & $3(7)$ & $3(12)$ & $0(0.0)$ & $3(12)$ \\
\hline February & $25(11.7)$ & $7(3.3)$ & $18(8.4)$ & $22(19.8)$ & $0(0.0)$ & $22(9.0)$ & $3(7)$ & $0(0.0)$ & $3(7)$ & $6(24)$ & $0(0.0)$ & $6(24)$ \\
\hline March & $28(13.1)$ & $4(1.9)$ & $24(11.2)$ & $23(20.7)$ & $3(2.7)$ & $20(18.0)$ & $2(4.7)$ & $0(0.0)$ & $2(4.7)$ & $2(8)$ & $0(0.0)$ & $2(8)$ \\
\hline April & $18(8.4)$ & $3(1.4)$ & $15(7.0)$ & $21(18.9)$ & $4(3.6)$ & $17(15.3)$ & $3(7)$ & $0(0.0)$ & $3(7)$ & $3(12)$ & $0(0.0)$ & $3(12)$ \\
\hline May & $20(9.3)$ & $4(1.9)$ & $16(7.5)$ & $19(17.1)$ & $1(0.9)$ & $18(16.2)$ & $3(7)$ & $1(2.3)$ & $2(4.7)$ & $4(16)$ & $0(0.0)$ & $4(16)$ \\
\hline June & $14(6.5)$ & $3(1.4)$ & $11(5.1)$ & $16(14.4)$ & $0(0.0)$ & $16(14.4)$ & $2(4.7)$ & $0(0.0)$ & $2(4.7)$ & $7(28)$ & $1(4)$ & $6(24)$ \\
\hline July & $29(13.6)$ & $3(1.4)$ & $26(12.1)$ & $0(0.0)$ & $0(0.0)$ & $0(0.0)$ & $5(11.6)$ & $1(2.3)$ & $4(9.3)$ & $0(0.0)$ & $0(0.0)$ & $0(0.0)$ \\
\hline August & $13(6.1)$ & $4(1.9)$ & $9(4.2)$ & $0(0.0)$ & $0(0.0)$ & $0(0.0)$ & $6(14)$ & $0(0.0)$ & $6(14)$ & $0(0.0)$ & $0(0.0)$ & $0(0.0)$ \\
\hline
\end{tabular}




\begin{tabular}{|c|c|c|c|c|c|c|c|c|c|c|c|c|}
\hline September & $12(5.6)$ & $0(0.0)$ & $12(5.6)$ & $0(0.0)$ & $0(0.0)$ & $0(0.0)$ & $5(11.6)$ & $1(2.3)$ & $4(9.3)$ & $0(0.0)$ & $0(0.0)$ & $0(0.0)$ \\
\hline October & $15(7.0)$ & $2(0.9)$ & $13(6.1)$ & $0(0.0)$ & $0(0.0)$ & $0(0.0)$ & $5(11.6)$ & $0(0.0)$ & $5(11.6)$ & $0(0.0)$ & $0(0.0)$ & $0(0.0)$ \\
\hline November & $15(7.0)$ & $0(0.0)$ & $15(7.0)$ & $0(0.0)$ & $0(0.0)$ & $0(0.0)$ & $4(9.3)$ & $0(0.0)$ & $4(9.3)$ & $0(0.0)$ & $0(0.0)$ & $0(0.0)$ \\
\hline December & $9(4.2)$ & $1(0.5)$ & $8(3.7)$ & $0(0.0)$ & $0(0.0)$ & $0(0.0)$ & $2(4.7)$ & $0(0.0)$ & $2(4.7)$ & $0(0.0)$ & $0(0.0)$ & $0(0.0)$ \\
\hline Total & $214(100)$ & $37(17.3)$ & $177(82.7)$ & $\begin{array}{l}11 \\
(100.0)\end{array}$ & $8(7.2)$ & $103(92.8)$ & $43(100)$ & $3(7)$ & $40(93)$ & $25(100)$ & $1(4)$ & $24(96)$ \\
\hline \multicolumn{4}{|c|}{ General Surgery (2017) } & \multicolumn{3}{|c|}{ General Surgery (2018) } & \multicolumn{3}{|c|}{ Urology (2017) } & \multicolumn{3}{|c|}{ Urology (2018) } \\
\hline January & $61(5.4)$ & $5(0.4)$ & $56(5.0)$ & $65(11.4)$ & $2(0.4)$ & $63(11.0)$ & $21(4)$ & $0(0.0)$ & $21(4)$ & $8(3.5)$ & $0(0.0)$ & $8(3.5)$ \\
\hline February & $81(7.2)$ & $5(0.4)$ & $76(6.7)$ & $110(19.3)$ & $1(0.2)$ & $109(19.1)$ & $45(8.6)$ & $0(0.0)$ & $45(8.6)$ & $41(17.7)$ & $0(0.0)$ & $41(17.7)$ \\
\hline March & $109(9.7)$ & $3(0.3)$ & $106(9.4)$ & 89 (15.6) & $4(0.7)$ & 85 (14.9) & $39(7.4)$ & $0(0.0)$ & $39(7.4)$ & $34(14.7)$ & $0(0.0)$ & $34(14.7)$ \\
\hline April & $97(8.6)$ & $5(0.4)$ & $92(8.2)$ & $108(18.9)$ & $8(1.4)$ & $100(17.5)$ & $40(7.6)$ & $4(0.8)$ & $36(6.8)$ & $67(29)$ & $1(0.4)$ & $66(28.6)$ \\
\hline May & $129(11.4)$ & $6(0.5)$ & $123(10.9)$ & $107(18.7)$ & $6(1.1)$ & $101(17.7)$ & $55(10.5)$ & $0(0.0)$ & $55(10.5)$ & $39(16.9)$ & $0(0.0)$ & 39 (16.9) \\
\hline June & $98(8.7)$ & $4(0.4)$ & $94(8.3)$ & $92(16.1)$ & $3(0.5)$ & 89 (15.6) & $41(7.8)$ & $0(0.0)$ & $41(7.8)$ & $42(18.2)$ & $0(0.0)$ & $42(18.2)$ \\
\hline July & $95(8.4)$ & $3(0.2)$ & $92(8.2)$ & $0(0.0)$ & $0(0.0)$ & $0(0.0)$ & $66(12.6)$ & $0(0.0)$ & $66(12.6)$ & $0(0.0)$ & $0(0.0)$ & $0(0.0)$ \\
\hline August & $121(10.7)$ & $2(0.2)$ & $119(10.5)$ & $0(0.0)$ & $0(0.0)$ & $0(0.0)$ & $43(8.2)$ & $0(0.0)$ & $43(8.2)$ & $0(0.0)$ & $0(0.0)$ & $0(0.0)$ \\
\hline September & $98(8.7)$ & $4(0.4)$ & $94(8.3)$ & $0(0.0)$ & $0(0.0)$ & $0(0.0)$ & $55(10.5)$ & $0(0.0)$ & $55(10.5)$ & $0(0.0)$ & $0(0.0)$ & $0(0.0)$ \\
\hline October & 89 (7.9) & $5(0.4)$ & $84(7.5)$ & $0(0.0)$ & $0(0.0)$ & $0(0.0)$ & $44(8.4)$ & $2(0.4)$ & $42(8)$ & $0(0.0)$ & $0(0.0)$ & $0(0.0)$ \\
\hline November & $97(8.6)$ & $5(0.4)$ & $92(8.2)$ & $0(0.0)$ & $0(0.0)$ & $0(0.0)$ & $34(6.5)$ & $0(0.0)$ & $34(6.5)$ & $0(0.0)$ & $0(0.0)$ & $0(0.0)$ \\
\hline December & $53(4.7)$ & $0(0.0)$ & $53(4.7)$ & $0(0.0)$ & $0(0.0)$ & $0(0.0)$ & $42(8.0)$ & $0(0.0)$ & $42(8)$ & $0(0.0)$ & $0(0.0)$ & $0(0.0)$ \\
\hline Total & $\begin{array}{l}1128 \\
(100)\end{array}$ & $47(4.2)$ & $1086(96.3)$ & $\begin{array}{l}571 \\
(100.0)\end{array}$ & $24(4.2)$ & $547(95.8)$ & $525(100)$ & $6(1.1)$ & $519(98.9)$ & $\begin{array}{l}231 \\
(100.0)\end{array}$ & $1(0.4)$ & $230(99.6)$ \\
\hline
\end{tabular}

N: Frequency. (\%): Percentage. 
Table 3. General causes of surgeries cancellation by surgical specialty

\begin{tabular}{|c|c|c|c|c|c|c|c|c|c|c|c|c|}
\hline Causes of Cancellation of Scheduled Surgeries & $\begin{array}{l}\text { Ort } \\
(2017)\end{array}$ & $\begin{array}{l}\text { Ort } \\
(2018)\end{array}$ & $\begin{array}{l}\text { Gin } \\
(2017)\end{array}$ & $\begin{array}{l}\text { Gin } \\
(2018)\end{array}$ & $\begin{array}{l}\text { Cx. Gen } \\
\text { (2017) }\end{array}$ & $\begin{array}{l}\text { Cx. Gen } \\
\text { (2018) }\end{array}$ & $\begin{array}{l}\text { Otor } \\
(2017)\end{array}$ & $\begin{array}{l}\text { Otor } \\
(2018)\end{array}$ & $\begin{array}{l}\text { Neu } \\
(2017)\end{array}$ & $\begin{array}{l}\text { Neu } \\
(2018)\end{array}$ & $\begin{array}{l}\text { Uro } \\
(2017)\end{array}$ & $\begin{array}{l}\text { Uro } \\
(2018)\end{array}$ \\
\hline Adverse patient conditions & $13(41)$ & $2(12)$ & $26(70.3)$ & $5(62.5)$ & $16(34)$ & $12(50)$ & $1(12.5)$ & $0(0.0)$ & $2(66.7)$ & $0(0.0)$ & $3(50)$ & $\begin{array}{l}1 \\
(100)\end{array}$ \\
\hline Short time for surgery & $4(13)$ & $1(6)$ & $0(0.0)$ & $0(0.0)$ & $4(8.5)$ & $0(0.0)$ & $0(0.0)$ & $0(0.0)$ & $0(0.0)$ & $0(0.0)$ & $0(0.0)$ & $0(0.0)$ \\
\hline Lack of surgical material and instruments & $6(19)$ & $4(24)$ & $2(5.4)$ & $0(0.0)$ & $0(0.0)$ & $2(8.3)$ & $3(37.5)$ & $0(0.0)$ & $0(0.0)$ & $0(0.0)$ & $0(0.0)$ & $0(0.0)$ \\
\hline Canceled by the surgeon & $1(3)$ & $3(18)$ & $2(5.4)$ & $0(0.0)$ & $1(2.1)$ & $3(12.5)$ & $0(0.0)$ & $0(0.0)$ & $0(0.0)$ & $0(0.0)$ & $0(0.0)$ & $0(0.0)$ \\
\hline Suspended by anesthesiology due to lack of preoperative assessment & $0(0.0)$ & $0(0.0)$ & $0(0.0)$ & $0(0.0)$ & $0(0.0)$ & $0(0.0)$ & $0(0.0)$ & $0(0.0)$ & $0(0.0)$ & $0(0.0)$ & $0(0.0)$ & $0(0.0)$ \\
\hline Inadequate pre-surgical preparation & $0(0.0)$ & $0(0.0)$ & $0(0.0)$ & $0(0.0)$ & $4(8.5)$ & $0(0.0)$ & $0(0.0)$ & $0(0.0)$ & $0(0.0)$ & $0(0.0)$ & $0(0.0)$ & $0(0.0)$ \\
\hline Lack or inadequate medical assessment & $1(3)$ & $2(2)$ & $1(2.7)$ & $0(0.0)$ & $0(0.0)$ & $0(0.0)$ & $0(0.0)$ & $0(0.0)$ & $0(0.0)$ & $0(0.0)$ & $0(0.0)$ & $0(0.0)$ \\
\hline No clinical record was found to determine the cause of cancellation & $0(0.0)$ & $0(0.0)$ & $0(0.0)$ & $0(0.0)$ & $5(10.6)$ & $0(0.0)$ & $0(0.0)$ & $0(0.0)$ & $0(0.0)$ & $0(0.0)$ & $0(0.0)$ & $0(0.0)$ \\
\hline Lack of laboratory tests & $3(9)$ & $0(0.0)$ & $3(8.1)$ & $2(25)$ & $5(10.6)$ & $0(0.0)$ & $0(0.0)$ & $0(0.0)$ & $0(0.0)$ & $0(0.0)$ & $0(0.0)$ & $0(0.0)$ \\
\hline The patient did not show up & $0(0.0)$ & $0(0.0)$ & $0(0.0)$ & $0(0.0)$ & $0(0.0)$ & $3(12.5)$ & $0(0.0)$ & $0(0.0)$ & $0(0.0)$ & $0(0.0)$ & $0(0.0)$ & $0(0.0)$ \\
\hline The patient was operated due to an emergency & $0(0.0)$ & $0(0.0)$ & $0(0.0)$ & $0(0.0)$ & $0(0.0)$ & $0(0.0)$ & $0(0.0)$ & $0(0.0)$ & $0(0.0)$ & $0(0.0)$ & $0(0.0)$ & $0(0.0)$ \\
\hline Canceled "or" Suspended "by Anesthesia & $0(0.0)$ & $1(6)$ & $0(0.0)$ & $0(0.0)$ & $5(10.6)$ & $2(8.3)$ & $4(50)$ & $1(100)$ & $0(0.0)$ & $0(0.0)$ & $3(50)$ & $0(0.0)$ \\
\hline The patient does not accept surgical procedure & $0(0.0)$ & $1(6)$ & $2(5.4)$ & $0(0.0)$ & $2(4.3)$ & $0(0.0)$ & $0(0.0)$ & $0(0.0)$ & $0(0.0)$ & $0(0.0)$ & $0(0.0)$ & $0(0.0)$ \\
\hline Lack of blood & $0(0.0)$ & $0(0)$ & $1(2.7)$ & $0(0.0)$ & $0(0.0)$ & $0(0.0)$ & $0(0.0)$ & $0(0.0)$ & $0(0.0)$ & $0(0.0)$ & $1(0.0)$ & $0(0.0)$ \\
\hline Others (lack of beds, errors in admission, repeated scheduling, lack of staff) & $3(9)$ & $2(12)$ & $0(0.0)$ & $0(0.0)$ & $5(10.6)$ & $2(8.3)$ & $0(0.0)$ & $0(0.0)$ & $0(0.0)$ & $1(100)$ & $2(0.0)$ & $0(0.0)$ \\
\hline Inconsistencies in the laboratory results & $1(3)$ & $1(6)$ & $0(0.0)$ & $1(12.5)$ & $0(0.0)$ & $0(0.0)$ & $0(0.0)$ & $0(0.0)$ & $1(33.3)$ & $0(0.0)$ & $3(0.0)$ & $0(0.0)$ \\
\hline The patient died & $0(0.0)$ & $0(0.0)$ & $0(0.0)$ & $0(0.0)$ & $0(0.0)$ & $0(0.0)$ & $0(0.0)$ & $0(0.0)$ & $0(0.0)$ & $0(0.0)$ & $4(0.0)$ & $0(0.0)$ \\
\hline Total & $32(100)$ & $17(100)$ & $37(100)$ & $8(100)$ & $47(100.0)$ & $24(100)$ & $8(100)$ & $1(100)$ & $3(100)$ & $1(100)$ & $\begin{array}{l}6 \\
(100)\end{array}$ & $\begin{array}{l}1 \\
(100)\end{array}$ \\
\hline
\end{tabular}

N: Frequency. (\%): Percentag. Ort: Orthopedy. Gin: Gynecology. Cx. Gen: General Surgery. Otor: Otolaryngology. Neu: Neurosurgery. Uro: Urology. 
Graph 1 shows that in 2017 of the total cancelled surgeries in the specialty of Orthopedy, $47 \%$ were attributable to the patient; $38 \%$ to the hospital and $16 \%$ to the medic. In 2018 the causes of cancellation of surgeries were attributable in equal proportion to the patient and to the hospital with a value of $35 \%$.

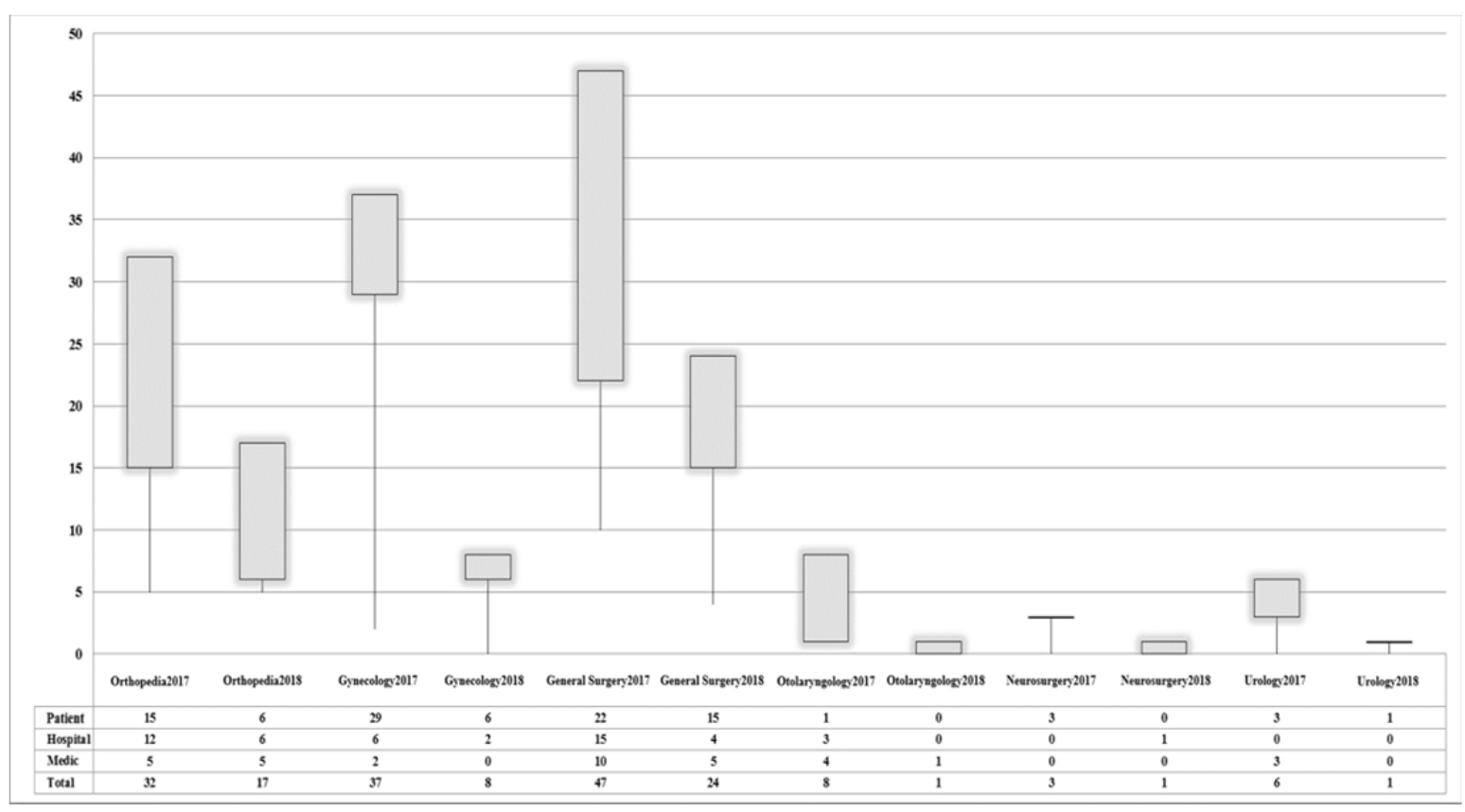

Graph 1. Factors attributable to surgeries cancellation

Of the total surgeries cancelled for Gynecology, $78.4 \%$ were attributable to the patient, followed by $16.2 \%$ attributable to the hospital and $5.4 \%$ to the medic. In 2018, the causes of surgery cancellation were attributable according to the records to the patient in $75 \%$ and to the hospital in $25 \%$. In the year 2017 in the specialty of General Surgery, $46.8 \%$ of surgery cancellations were attributable to the patient, followed by $31.9 \%$ attributable to the hospital and $21.3 \%$ to the doctor. In 2018 the causes were attributable to the patient in $62.5 \% ; 16.7 \%$ to the hospital and $20.8 \%$ to the medic. In the specialty of Otorhinolaryngology, the causes of cancellation of surgery for 2017 were attributable to the patient in $12.5 \%$, to the hospital in $37.5 \%$ and to the medic in $80 \%$. In 2018 the canceled surgery was not attributed to the medic. In the year 2017 of the total of surgeries cancelled in the specialty of Neurosurgery, the causes of cancellation of surgery were attributable only to the patient with $100 \%$. In 2018 the cancelled surgery was attributed to the hospital with $100 \%$. In the year 2017 of the total of surgeries cancelled in the specialty of Urology, the causes of cancellation of surgery were attributable to the patient in $50 \%$ and to the medic in $50 \%$ of the total of surgeries cancelled. In 2018 , the cancelled surgery was $100 \%$ attributed to the patient. (Graph 1).

The Neuronal Multilayer Perceptron Network model shows that the factor with the highest normalized weigth for surgeries cancellation with a value of $100 \%$ was the patient factor. (Graph 2). 


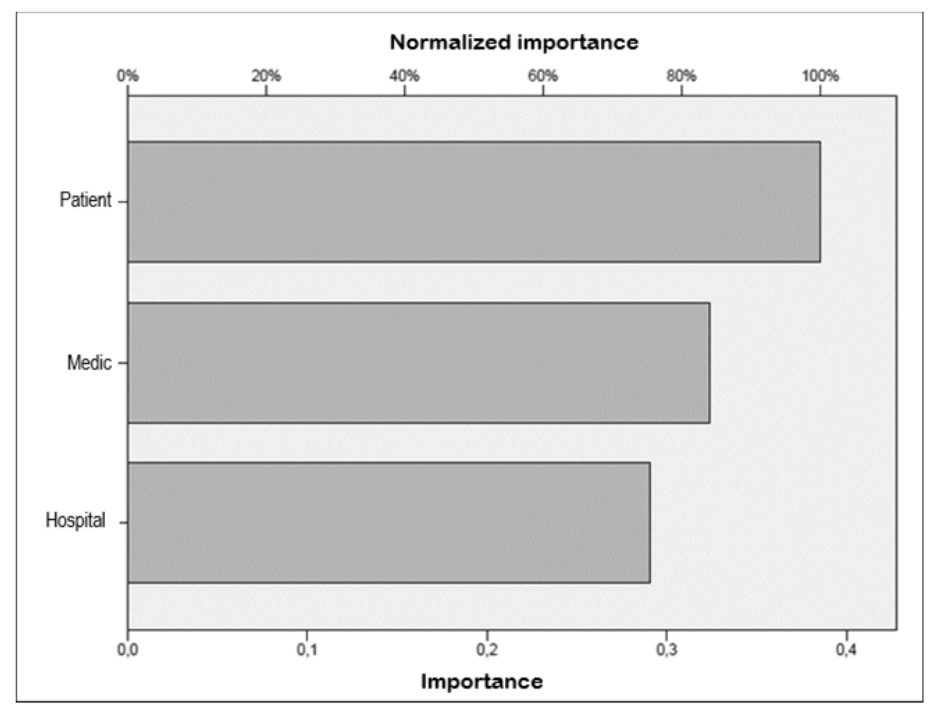

Graph 2. Smoothed importance of the attributable factors for surgeries cancellation

The GINI coefficient was 0.77 , which shows the degree of inequality or disproportion between the factors (Graph $3)$.

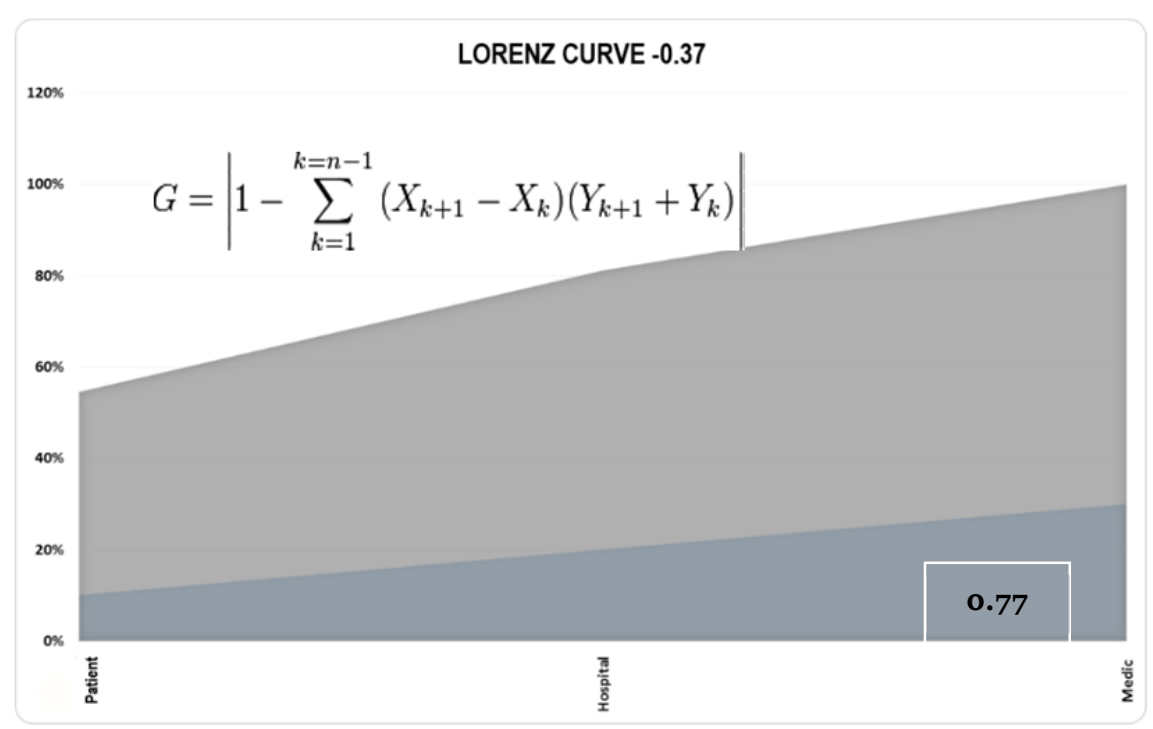

Graph 3. Degree of inequality between the factors according to the GINI coefficient

\section{Discussion}

Reviewed studies do not offer a consensus on what should be the optimal rates for surgical suspension, even the most important reasons such as those related to the patient represent a challenge. Therefore, each institution deserves its own analysis of the attributable factors profile (Fayed et al., 2016). In our results it was found that the percentage of surgeries cancellation ranges from $1.0 \%$ to $17.3 \%$ by surgical specialty, demonstrating that the medical specialties which presented more cancelled procedures are General Surgery, Orthopedy, Otolaryngology and Gynecology. When comparing our results with the ones obtained by other studies, the cancellation rate was considered low, according to the results presented by (Jimenez et al., 2006), that is to say, they would be within the range of what it would be considered as acceptable, which according to Jimenez it would be in the range of $1 \%$ to $40 \%$, taking into account that this upper limit value is considered very high.

Out of a total of (3339) surgeries that were scheduled in 2017, 4\% (133/3339) were cancelled. On the other hand, during 2018 from January to June, (1733) elective surgeries were scheduled, from which 3\% (52/1733) were 
cancelled, these average cancellation rates were within the ranges established by other studies such as those proposed by (Tait et al., 1997; Schofield et al., 2005; Jimenez et al., 2006; Sanjay, Dodds, Miller, Arumugam, \& Woodward, 2007; Dhafar et al., 2015; Yu, Xie, Luo, \& Gong, 2017; Beijnen et al., 2018).

Studies demonstrate that climatic factors and diseases related to these events such as febrile and respiratory conditions were sufficient cause for the surgeries cancellation as exposed by (Grover, Gagnon, Flegel, \& Hoey, 1983). Our data showed that during the months of April and October of both years, a low number of surgeries were scheduled because of the rainy season, something similar happened during the months of January and December because in Colombia it is holiday season. However, surgical procedures were canceled. This could explain the fact that one of the reasons for surgeries cancellation was adverse condition presented by the patient, such as climatic factors or recreational interests, which could have been avoided by doing confirmatory calls (Grover et al., 1983).

Different cancellation rates were evidenced by surgical specialty in our study, general surgery, orthopedy and gynecology surgery showed the highest cancellation rates, similarly to what was reported by (Argo et al., 2009; Laisi, Tohmo, \& Keränen, 2013; Fayed et al., 2016).

A prospective study could consider real-time solution dynamics with predictive elements such as those proposed by the analysis models used in our investigation, such as the Neuronal Multilayer Perceptron Network (NMPN), which determined that the highest ratio of causes for cancellation of scheduled surgeries is due to patients with a $100 \%$ of normalized importance.

The investigation yielded elements to establish monitoring and control strategies, especially with patients to avoid absenteeism and improve the quality of the surgical service respecting the patient's autonomy (Díaz-Pérez et al., 2018; Díaz-Pérez et al., 2019).

The institutions should consider the study of the characteristics of the profiles of the factors for the cancellation of surgery, even by specialty, understanding that the low rates in some of them, does not imply that programs should not be continuously developed and analyzed to establish the common and specific factors by specialty, keeping in mind the characteristics of environmental and sociocultural phenomena of each region. The calculations made as the GINI coefficient allowed to determine the degree of inequality between the factors, as well as the (NMPN) determined as the most important reason for the surgeries cancellation those related to the patients.

\section{Competing Interests Statement}

The authors declare that there are no competing or potential conflicts of interest.

\section{References}

Aguirre-Gas, H. G., \& Vázquez-Estupiñán, F. (2006). El error médico. Eventos adversos. Cirugía y Cirujanos, 74(6), 495-503.

Antaurco, L. M., \& Méndez, V. M. (2018). Evento Adverso Quirúrgico: Algoritmo y Clasificación. Revista Médica Carriónica, 4(4), 1-6.

Applications of Information Systems to Operating Room Scheduling | Anesthesiology | ASA Publications. (s. f.). Recuperado 10 de abril de 2019, de http://anesthesiology.pubs.asahq.org/article.aspx?articleid=1948800

Argo, J. L., Vick, C. C., Graham, L. A., Itani, K. M., Bishop, M. J., \& Hawn, M. T. (2009). Elective surgical case cancellation in the Veterans Health Administration system: identifying areas for improvement. The American Journal of Surgery, 198(5), 600-606. https://doi.org/10.1016/j.amjsurg.2009.07.005

Barbenza, A. M. (2018). El Consentimiento Informado: algo más que un contrato. Cuadernos de Cirugía, 14(1), 7-8. https://doi.org/10.4206/cuad.cir.2000.v14n1-01

Beijnen, U. E., Caillouette, C. N., Flath-Sporn, S. J., Maclellan, R. A., Sanchez, K., Labow, B. I., ... Taghinia, A. H. (2018). Factors Associated With Late Surgical Cancellations in Pediatric Plastic and Oral Surgery. Annals of plastic surgery, 80(4), 412-415. https://doi.org/10.1097/SAP.0000000000001262

Canales, M. G., Macario, A., \& Krummel, T. (2001). The surgical suite meets the new health economy1. Journal of the American College of Surgeons, 192(6), 768-776. https://doi.org/10.1016/S1072-7515(01)00830-4

Cho, H.-S., Lee, Y., Lee, S., Kim, J., \& Kim, T. (2019). Reasons for Surgery Cancellation in a General Hospital: A 10-year Study. International journal of environmental research and public health, 16(1), 7. https://doi.org/10.3390/ijerph16010007

Corona Martínez, L., \& Fonseca Hernández, M. (2010). Un modelo simplificado del proceso de atención médica. Implicaciones asistenciales, docentes e investigativas. MediSur, 8(2), 34-37. 
De la Cruz Injante, C. R., Zapatero Choy, L. C., \& Medina Gaspar, E. E. (2018). Nivel de cumplimiento de las funciones de la enfermera en la seguridad de la cirugía en sala de operaciones en un Hospital de la Policía, Lima, julio-agosto 2018.

Dhafar, K. O., Ulmalki, M. A., Felemban, M. A., Mahfouz, M. E., Baljoon, M. J., Gazzaz, Z. J., \& Al-Hothali, F. T. (2015). Cancellation of operations in Saudi Arabian hospitals: Frequency, reasons and suggestions for improvements. Pakistan journal of medical sciences, 31(5), 1027. https://doi.org/10.12669/pjms.315.7932

Díaz-Pérez, A., Vega Ochoa, A. D., \& Romero Oñate, Z. (2018). The Informed Consent/Assent from the Doctrine of the Mature Minor. Global journal of health science, 10(8). https://doi.org/10.5539/gjhs.v10n8p124

Díaz-Pérez, A., Barrios Puerta, Z., \& Mendoza Cataño, C. (2019). Care and communication from nurses to families of hospitalized patients in an intensive care unit.

Díaz-Pérez, A. (2019). Damages and Perjuries, Demand, N Damages and Perjuries, Demand, N Negligence As The Main Medical Error By The Surgical Team: Awareness Surgical And Praxis. jmcrr, 2(6), 268-276.

Díaz Koo, C. J. (2019). Características de los pacientes con estancia prolongada en el servicio de cirugía general del Hospital Nacional Almanzor Aguinaga Asenjo.

Dobarro, A. B., Avión, R. C., Ruiloba, M. S. L., Lima, A. V., Cendón, M. O., García, N. F., ... Aira, A. C. (2019). Análisis retrospectivo de las suspensiones quirúrgicas y de los factores influyentes durante 8 años. Cirugía Española, 97(4), 213-221. https://doi.org/10.1016/j.ciresp.2019.01.006

Eugenio Ortiz, C., \& Alvarado Rodriguez, A. (2014). CAUSAS DE DIFERIMIENTO ANESTESICO QUIRURGICO, EN EL HOSPITAL GENERAL DE TLALNEPANTLA, VALLE CEYLAN EN EL PERIODO ENERO DE 2013 A JUNIO DE 2013.

Fayed, A., Elkouny, A., Zoughaibi, N., \& Wahabi, H. A. (2016). Elective surgery cancelation on day of surgery: An endless dilemma. Saudi journal of anaesthesia, 10(1), 68. https://doi.org/10.4103/1658-354X.169479

Gamboa Niño, A. J., \& Rodríguez Montaño, M. L. (2017). Diseño de un modelo de programación para el servicio de salas de cirugía de una clínica universitaria en Bogotá.

García Cordova, N. (2019). Nivel de Seguridad del Paciente que Brinda la Enfermera en el Centro Quirúgico-Hospital Victor Lazarte Echegaray.

Gaviria Gomez, M. V. (2015). Análisis Jurisprudencial Sentencia 17.918 del Consejo de Estado Responsabilidad Médica.

Gaviria-García, G., Lastre-Amell, G., \& Suárez-Villa, M. (2014). Causas que inciden en cancelación de cirugías desde la percepción del personal de salud. Enfermería universitaria, 11(2), 47-51. https://doi.org/10.1016/S1665-7063(14)72664-8

Grover, S., Gagnon, G., Flegel, K. M., \& Hoey, J. R. (1983). Improving appointment-keeping by patients new to a hospital medical clinic with telephone or mailed reminders. Canadian Medical Association Journal, 129(10), 1101.

Guillén, J. M., Bernadó, A. J., Solanas, J. A. G., Guedea, M. E., Villahoz, E. R., \& Díez, M. M. (2012). Cancelación en CMA: Incidencia y causas. Cirugia espanola, 90(7), 429-433. https://doi.org/10.1016/j.ciresp.2011.05.007

Jimenez, A., Artigas, C., Elia, M., Casamayor, C., Gracia, J. A., \& Martinez, M. (2006). Cancellations in ambulatory day surgery: Ten years observational study. Ambulatory Surgery, 12(3), 119-123. https://doi.org/10.1016/j.ambsur.2005.09.002

Laisi, J., Tohmo, H., \& Keränen, U. (2013). Surgery cancelation on the day of surgery in same-day admission in a Finnish hospital. Scandinavian Journal of Surgery, 102(3), 204-208. https://doi.org/10.1177/1457496913492626

Macarthur, A. J., Macarthur, C., \& Bevan, J. C. (1995). Determinants of pediatric day surgery cancellation. Journal of clinical epidemiology, 48(4), 485-489. https://doi.org/10.1016/0895-4356(94)00160-R

Muñoz, L., Reyes, L. E., Infante, S., Quiroga, J., Cabrera, L., Obando, N., \& Banghara, L. (2018). Cancelación de procedimientos electivos y su relación con la valoración preanestésica. Revista Repertorio de Medicina y Cirugia, 27(1), 24-29. https://doi.org/10.31260/RepertMedCir.v27.n1.2018.128

Nepote, M. H. A., Monteiro, I. U., \& Hardy, E. (2009). Association between operational indexes and the utilization rate of a general surgery center. Revista latino-americana de enfermagem, 17(4), 529-534. 
https://doi.org/10.1590/S0104-11692009000400015

Olguín-Juárez, P. (2018). El análisis factorial para aumentar el rendimiento del quirófano y disminuir la cancelación de cirugía electiva. Cirujano General, 40(2), 78-86.

Perroca, M. G., Jericó, M. de C., \& Facundin, S. D. (2007). Surgery cancelling at a teaching hospital: implications for cost management. Revista latino-americana de enfermagem, 15(5), 1018-1024. https://doi.org/10.1590/S0104-11692007000500021

Quesquén, R., \& Alfredo, S. (2018). Causas e implicancias económicas en la suspensión de intervenciones quirúrgicas en el periodo 2012-2014 en el Hospital Nacional Dos de Mayo.

Sanjay, P., Dodds, A., Miller, E., Arumugam, P. J., \& Woodward, A. (2007). Cancelled elective operations: an observational study from a district general hospital. Journal of health organization and management, 21(1), 54-58. https://doi.org/10.1108/14777260710732268

Schofield, W. N., Rubin, G. L., Piza, M., Lai, Y. Y., Sindhusake, D., Fearnside, M. R., \& Klineberg, P. L. (2005). Cancellation of operations on the day of intended surgery at a major Australian referral hospital. Medical Journal of Australia, 182(12), 612-615.

Tait, A. R., Voepel-Lewis, T., Munro, H. M., Gutstein, H. B., \& Reynolds, P. I. (1997). Cancellation of pediatric outpatient surgery: economic and emotional implications for patients and their families. Journal of clinical anesthesia, 9(3), 213-219. https://doi.org/10.1016/S0952-8180(97)00032-9

Trincado Agudo, M. T., \& Fernández Caballero, E. (1995). Calidad en enfermería. Revista cubana de enfermería, 11(1), 1-2.

Trouiller, P., Lopard, E., Mantz, J., \& Farman, T. (2012). De la complication médicale à l'indemnisation du préjudice. Annales françaises d'anesthésie et de réanimation, 31, 626-631. Elsevier. https://doi.org/10.1016/j.annfar.2012.04.006

Vargas Villanueva, F. (2018). La responsabilidad civil objetiva del médico y daño moral. Revista CONAMED, 9(2), $14-21$.

Vayre, P., \& Vannineuse, A. (2003). Le risque annoncé de la pratique chirurgicale: Complications-Dommages-Responsabilité-Indemnisation. Springer Science \& Business Media.

Yu, K., Xie, X., Luo, L., \& Gong, R. (2017). Contributing factors of elective surgical case cancellation: A retrospective cross-sectional study at a single-site hospital. BMC surgery, $17(1), 100$. https://doi.org/10.1186/s12893-017-0296-9

\section{Copyrights}

Copyright for this article is retained by the author(s), with first publication rights granted to the journal.

This is an open-access article distributed under the terms and conditions of the Creative Commons Attribution license (http://creativecommons.org/licenses/by/4.0/). 